\title{
FISCAL DECENTRALIZATION REFORM AND ITS IMPACTS ON PRIMARY EDUCATION SERVICE DELIVERY IN TANZANIA: THE CASE OF DODOMA MUNICIPAL COUNCIL
}

\author{
C 2019 Dr. Paul Mtasigazya
}

\begin{abstract}
Dr. Paul MTASIGAZYA (PhD), (Lecturer) Department of Social Studies, The Mwalimu Nyerere Memorial Academy- Zanzibar Campus. P.O. Box 307, Zanzibar. Tanzania, e-mail: p.anton75@ yahoo.com. Mobile phone: +255714449030

Abstract. This study is about fiscal decentralization reforms implemented in Local Government Authorities (LGAs) in Tanzania with special focus on Primary Education Service Delivery in Dodoma Municipal Council. The study investigated the question of poor performance of the municipal council in primary education service delivery despite the reforms undertaken to devolve the finances and functions to the council. It aimed to find out the extent and manner the fiscal decentralization has been implemented and its effects on the council's performance on primary education service delivery. The study is based on data collected through interview and documentary review. It has been observed that despite to fiscal decentralization reforms, still there has been no significant improvement in quantitative and qualitative primary education service delivery in the council. This study further noted that the practice of fiscal decentralization such as intergovernmental fiscal transfer, (grants) and local government own sources of revenues are not adequate. The devolved funds also are characterized by conditional ties which undermine the autonomy and priorities of the Council. The study also noted that financial capacity of the council is weak despite the reform which have not provided for the expenditure on school infrastructure, furniture and poor academic performance to standard seven examinations and inadequate funds disbursed to the council, have led to poor primary education service delivery. The study recommends that council should be assured of autonomy in fiscal control and management to ensure qualitative and quantitative primary education service delivery.
\end{abstract}

Keywords: Fiscal Decentralization Reform, Primary Education Services Delivery

DOI: $10.31132 / 2412-5717-2019-48-3-30-48$

\section{Introduction and Background to the Study}

Local governments in Tanzania were initially established during the British colonial rule, following the enactment of the native authority ordinance Cap.72 of 1926 (Ngware, 1997). At this time local governments were responsible for maintenance of law and order, collection of poll tax, prevention of soil erosion and construction of feeder roads as well as the promotion of agricultural activities (Kessy, 2011). However, they faced a number of problems such as lack of adequate finance, lack of financial management autonomy, and poor quality of the local government staff who were mostly primary school leavers who could not deliver services effectively.

Likewise as in the other African countries such as Kenya and southern Africa, Tanzania inherited a political system from British colonial power that fostered strong state centralism allowing only minimal popular participation (Ngware, 1997). The colonial state lacked accountability, and made no efforts to be transparent and thus, the colonial system of governance and administration was undemocratic (Mtasigazya, 2019). This was the legacy of the post colonial regime inherited at the independence in 1961.

In 1972 local governments were abolished and replaced by District and Regional Directorates ,professional and technocrats were appointees of the central government, and they were accountable and responsible not to the people in the respective district $s$ and regions 
but to the president at centre (Max, 1991). The local and central government responsibilities were merged, this meant to result into strong central organization for coordinating and supervising rural development, which it was believed would increase people's control of development process in their own areas. Unfortunately, the power given to the people was actually hijacked by the bureaucrats who tended to make decisions on behalf of their people (Matete, 2016). Primary and adult education were decentralised to regional authorities in 1972, while secondary education, teacher education and higher education were left under the control of the central government through the Ministry of Education (Galabawa, 1990; Matete, 2016).

However, things did not go as it was expected as Max (1991) states that the period was associated with rapid deterioration of conditions in urban areas, primary schools lacked text books and their buildings remained unmaintained, drainage and sewers remained unblocked, roads went unattended and dispensaries lacked essential drugs. An outbreak of cholera in many urban areas in year 1976 prompted the government to set up an investigation team and that recommended the reinstatement of urban local government. Therefore, local governments were re-established in 1984. The move to re-establish local authorities started in 1982, when several pieces of legislation were passed (Mtasigazya, 2018a). These include Act No. 7 of 1982, which provides for establishment of district authorities and Act No. 8 of 1982, which provided for control of financial matters in local government (Mukandala, 2000). The reestablished institutions were expected to solve socio-economic problems of the people (Ngware and Haule, 1992). In order to achieve the expected outcomes, the reconstituted local governments were expected to create an in built management capacity so as to deliver qualitative and quantitative public services.

On the other hand, there is a general consensus in Tanzania that the re-established local governments did not perform and behave to the expectations of the people. The low performance levels of local government were indicated by the declining quality and quantity of public services, for example local government experienced deterioration of health services and shortage of health facilities in various dispensaries and hospitals, poor condition of both rural and urban roads. All these were persistent problems which prompted the reestablishment of local government authorities. However, the move from decentralization by deconcentration of 1972 to the re-instatement of local government in 1982, faced pertinent problems (Liviga, 1992). Thus, local government continued to be poor in performance as such the public perceived local government as inefficient and unable to deliver public goods and services effectively.

Nyalali Commission Report of (1992) and Liviga (1992) also observed that local authorities were not autonomous and therefore recommended that local government authorities be given more freedom and autonomy for their proper functioning. The central government was required to limit its tight control over government in respect of financial management and utilization and other matters. The envisaged local government reforms intend to create inbuilt management of finance and administrative matters as well as enhancing democratic governance (Ngware, 1999).

Before the start of the reform, the policy paper was initiated by central government; that is local government reform agenda in 1996, and Local Government Policy Paper (1998). Earlier local government reform had been one of the components of civil service reform program launched in 1993. The government started to reform local government based on the argument that the central government cannot be successfully reformed without reforming local government (Rugumamu, 1998). The main objective for the reform has been to improve services in qualitative and quantitative terms, and the strategy to achieve the above objective is through decentralization by devolution (Mtasigazya, 2018b). All councils were involved in far-reaching changes. Moreover, the study conducted by Fjeldstad (2004), revealed that the 
councils' capacity to absorb the changes was low, the program was over stated and sectoral ministries were reluctant to devolve power to local government authorities. Some of the factors involve resistance of both the central government and local government to change. As such local government continues to perform poorly in terms of service delivery.

Furthermore, URT (2005) and Mtasigazya (2018c) contended that, fiscal decentralization of service delivery has not adequately improved primary education services in Tanzania. As such the increase of enrolment has resulted in overcrowding of the classrooms, lack of adequate textbooks, and the book to pupil ratio of 1:18, 1:12 in rural and urban areas respectively. So, despite the fiscal decentralization reform, the local government authorities continue to perform poorly in primary education service delivery.

\section{Statement of the Problem}

It is almost two decades (2000-2019), since the Tanzanian government started to implement fiscal decentralization reform by devolving more fiscal power to local authorities such as financial mobilization, utilization and management with overall objective to improve performance of local government in services delivery. This effort was expected to create inbuilt management to deliver effectively and efficiently public services.

However, the studies indicate that the performance of local government is still dismal and some of the local government authorities in Tanzania have inadequate capacity and integrity to manage well increased fiscal autonomy and service delivery. For instance, Fjeldstad (2003; Mtasigazya, 2018b) confirmed that due to shortage of adequate funds, no development activities are undertaken through council's financial sponsorship. Further more, surveys conducted by Fjeldstad (2003), comprised of 126 respondents who saw few tangible benefits for tax system they paid. Only $9 \%$ of respondent agreed that most revenue collected was used to provide services. In Kilosa less than $3 \%$ of respondents said revenues were used to provide services while $50 \%$ respondents said that revenues collected were not used to provide services and majority of $51 \%$ of respondents agreed that people should refuse to pay tax until services had been improved (Fjeldstad, 2003; Mtasigazya, 2018a). Furthermore, school infrastructure such as classrooms, latrines, teachers, houses for the teachers, laboratories still are not adequate as such the pupil to teachers ratio is 30:1 as well book to pupil ratio is 1:13-15 which still a problem (Dodoma Municipal Council Performance Report, 2005; Matete, 2016). Also, the problem of desks still exists in many schools in Dodoma Municipality currently desk pupils ratio is 1: 4-5 and some pupils do not have desks as such they study while sitting on the floor in their class rooms which affect learning negatively .

Furthermore, enrolment of pupils has increased and outpaced the number of the classrooms, teachers recruited and deployed as such the Council's performance report in 2005 indicated there was deficit of $366(23 \%)$ teachers in Dodoma municipality. Also, the report indicated deficit of 168 classrooms (49\%), shortage of 625 houses (84\%) and latrines 1366 $(61 \%)$ of the deficit. All these deficits are/were attributed to lack of adequate funds particularly the funds disbursed by central government to the council for primary education services (Dodoma Municipal Performance Report, 2018; Matete, 2016). Furthermore, Ndalichako and Roy (2005) note that financial flow from the central government to local authorities involves complex process of disbursement such as three Ministries (MOEC, MOF, PORALG) due to bureaucratic procedures and red tape which result into delay of salaries to the teachers. Economic Research Bureau, (ERB) (1997) pointed out that local government in Tanzania roughly collect $3-5 \%$ percent of all public sector spending while spending $20 \%$ due to costly tax administration. The fore mentioned studies have said less on the lack of fiscal management autonomy in local government authorities and to what extent have contributed to poor performance in primary education services delivery. Therefore, this study intends to investigate the lack of fiscal autonomy for local government and to what extent this has 
contributed to poor primary education services delivery despite fiscal decentralization reform in Tanzania. Furthermore, this study was guided by the following research objectives: -

\section{Specific Objectives}

- To examine how fiscal decentralization has contributed to the availability of teaching staff and school infrastructures in Dodoma Municipality.

- To examine the pattern of enrolments and academic performance in Primary Schools in Dodoma Municipality.

\section{Research Questions}

- What is contribution of fiscal decentralization on the availability of teaching staff and school infrastructures in primary schools in Dodoma Municipality?

- What are the trends of enrolment of pupils and academic performance in primary schools in Dodoma Municipal Council?

\section{Literature Review and Theoretical Framework}

The term local government is defined by Warioba (1991) as that part of government in the country operating at local level, which is democratically elected and has functions in a defined area of jurisdiction. Mwaikusa (1985) notes that local government as involvement of people through democratically elected representatives in the administration of their own affairs at their locality. These people must have power over their own social and economic development activities as such this power has to come from them. In this study therefore, local government is defined as the public authorities including appointed and elected officials operating at local level for the purposes of promoting local democracy and development.

Furthermore, different authors have identified features of local government. For instance, Mwaikusa (1985) identified three essential features namely, (i) separate autonomy and legal status distinct from that of central government (ii) power to raise their own revenue and spend on the discharge of function as assigned to them by law, and (iii) power to make decisions as responsible organs in their own rights and not as an extension of central government.

According to Liviga, (1992) local government is a very important organ because of the duties it is expected to discharge; it will also efficiently use the resources and energies of the people and assist the central government by interpreting national needs and goals to the people as well as local needs and traditions to the central authorities. Also according to the Constitution of United Republic of Tanzania (1977), local governments are expected to play an important developmental and democratization functions as stated in article 146 (2 and 3). Also De mellow (1982) contends that, there is no better and cheaper way to bring a government presence to the remote or poverty-ridden areas of the country than to use local governments. Thus, the above importance justifies the significance and necessity of local government. To be effective, local government need to have autonomy and discretionary authority. These studies have enumerated features for autonomous and effective local governments but did not consider how these features promote local governments' effectiveness in social services in particular primary education services delivery in Tanzania.

Furthermore, the analysis of empirical studies indicate that there is one study on fiscal decentralization by Fjelstad (2003), which dwelt on allocation of expenditure to education sectors and citizen satisfaction on service delivery. It further dealt with new challenges facing local government revenue enhancement. Ndalichako and Roy (2005) dealt with financial flow from the central government to primary schools and found that it involved complex process as 
discussed. Dodoma Municipal Performance Report (2005) indicated poor performance of the council in primary education services was attributed to inherent factors as afore mentioned. Therefore, this study is based on the assumption that poor performance of local government authorities over years since the advent of reform in Tanzania has been contributed by lack of autonomy in financial management due to central government interference. The study attempts to depart from other studies such as Max (1991), Fjelstad (2003), and Matete, (2016), Liviga (1992), which attributed poor performance to the factors inherently within the councils themselves. The study explained the poor performance of local councils as a result of central government interference in financial mobilization and utilization in spite of fiscal decentralization reforms.

\section{Theory Guiding the Study: Decentralization Theory}

There are different approaches toward the study of local government which include the orthodox, Marxist, statism, public choice and decentralization approach. However this study will be guided by the fiscal decentralization approach. The reason why this approach is chosen is due to the fact that the other approaches do not address the historical development of local government and the issue of the fiscal autonomy. The issues can be well and intensively explained by fiscal decentralization approach and devolution as far as devolution of functions and financial resources from the central government to local government in service delivery is concerned. Rationale for the choice of fiscal decentralization approach is demonstrated below:-

Oates (1993), contended that fiscal decentralization approach is widely advocated on the premise that it improves economic performance by increasing economic efficiency in the provision of public services. Matete (2016) also support that decentralization approach has been shown to strengthen social capital and encourage political participation that usually leads to higher level of accountability in government behaviour and thus strengthening democratic institutions. Fiscal decentralization reduces misallocation of public resources. Resources that would otherwise be diverted are then availed for the public goods and services. Demello (1998), contends that fiscal decentralization approach is expected to promote sound macro economic management through efforts that stream line public sector activities, reduce operational and information cost of service delivery. Therefore, the above rationale necessitated the choice of this approach.

\section{Research approach and design}

This study, employed both qualitative and quantitative approaches because the information about fiscal decentralization in local government specifically Dodoma municipal council and its effects on local government performance on primary education service delivery are both qualitative and quantitative in nature.

\section{A Case Study Research Design}

A case study refers to small inclusive and extensive study of an individual (s) or area whereby an investigator employs all his/her skills and methods so as to allow systematic gathering of enough information about phenomenon, to permit one understands on how it functions as unit of society (Devi, 1997). The study was conducted in Dodoma Municipal Council which is populated by 410,956199 people, whose 487211 are female while ,4694.494 are female (URT, 2012). In 1973 plans were made to move the capital of Tanzania to Dodoma and the national assembly moved while the government moved to Dodoma in 2015 when the fifth phase president came in power while Dar es Salaam remains the commercial capital. The rationale for selecting this case study is due to the fact that most of the studies related to fiscal 
decentralization and service delivery have been conducted in other regions and Districts such as Ilala, Bagamoyo, Iringa, Mwanza just to mention a few. So, it is for this reason which motivated researcher to undertake this study in Dodoma.

\section{Sample and Sampling Techniques}

The sample for this study was drawn from three categories namely, local government staff (officials) teachers and pupils from Dodoma municipal council. For possible access and manageability, the sample comprised 138 informants of whom there were 30 teachers, 100 pupils and 8 local government staff (respondents). As portrayed, the sample was heterogeneous in character, aiming at capturing and getting information from varied groups of the informants. The study made use of five primary schools. Purposive sampling was employed so as to get the private primary school and public primary schools situated in Dodoma town. Those primary schools were selected with the expectation that their teachers and pupils would be in better position to provide useful information relevant to the study taking into account their varied experiences and attitudes. The primary schools involved in the study were Kizota, Kaloleni, Msalato, Chidachi public primary schools and Tumaini private primary Schools.

\section{Sampling of the respondents}

Purposive sampling procedure enabled the researcher to select thirty (30) teachers who met the criteria that were set by the researcher. These criteria used were based on sex where equal number (15) teachers female and (15) male teachers were purposively selected from each primary school. There were also 100 pupils and 8 local government staff. So the total number of respondents were 138. All these categories of respondents selected were the key beneficiaries of the primary education development programme within the aspect of fiscal decentralization in local government and its effects on primary education service delivery. Purposive sampling technique enabled the researcher to select all categories of respondents in Dodoma Municipality. The total composition of the respondents in the study is presented in the Table 1 below.

Table 1

Sample Distribution of Teachers, Pupils and Local Government Staff

\begin{tabular}{|l|c|c|c|}
\hline \multicolumn{1}{|c|}{ Category of Respondents } & \multicolumn{3}{c|}{ Respondents by Gender } \\
\hline Teachers & Female & Male & Total \\
\hline Pupils & 15 & 15 & 30 \\
\hline Local government staff & 50 & 50 & 100 \\
\hline
\end{tabular}

Sources: Field data, April, 2019

\section{Data Collection Techniques}

In this study in-depth interview was used as the method of primary data collection. This method was further complemented by documentary review. Semi structured interview was used to collect data from the teachers, local government staff and pupils as it was means of obtaining deeper information, to ensure clarity the interview was designed in a simple manner. Furthermore, documentary review which included a review of the potential documents Reports on local government performance in primary education services delivery were also reviewed. This method was used to get the availability of school infrastructures, teaching staff, funds disbursed to the primary school from the central government through 
council, the information obtained were used to supplement the information gaps of interview as primary source of data.

\section{Data Analysis Techniques}

Data collected from the field were analysed using content analysis. This is a method used for analysing data which were qualitative in nature, specifically data obtained from indepth interviews and documentary review, such as field notes and local government reports on fiscal decentralization and primary education service delivery. Content analysis consisted of reading and categorising the responses and transcribing them in a way that allowed identification of similarities and differences in order to develop themes and sub-themes relating to the research objectives, such as the availability of school infrastructures in primary schools and funds devolved to the local government for primary education service delivery. The data collected were then categorised according to their relevant research themes and sub-themes to allow coherent discussion of the research findings. For example, the data relating to the availability of school infrastructure and pattern of academic performance for pupils. Content analysis enabled the researcher to analyse primary data systematically and objectively so as to determine the pattern of responses and opinions given by the respondents in relation to the research questions. This facilitated the making of inferences from the qualitative data and coherence of the research findings. On the other hand, descriptive statistics and cross-tabulation were used to analyze the quantitative data that were mainly obtained from the documentary review. The quantitative techniques were used mainly for descriptive purposes. In particular, such data on the trend of academic performance each primary school and other information gathered from respondents and analysed using frequencies and percentages.

\section{Presentation of the Findings and Discussion Availability of School Infrastructure in Primary Schools}

Availability of school infrastructures was assessed basing on whether the classrooms, desks, latrines, teachers' houses were sufficient to the number of students and teachers in respective primary schools. Thus the findings presented below indicate the adequacy, reason for the deficit and required infrastructures on the above mentioned aspects.

Table 2

Responses from teachers on availability of Classrooms in Dodoma Municipality

\begin{tabular}{|c|c|c|c|}
\hline $\begin{array}{c}\text { Category } \\
\text { of respondents }\end{array}$ & $\begin{array}{c}\text { Response on adequacy } \\
\text { of classrooms }\end{array}$ & $\begin{array}{c}\text { Response a deficit } \\
\text { of classrooms }\end{array}$ & $\begin{array}{c}\text { Partly adequacy } \\
\text { of classrooms. }\end{array}$ \\
\hline Teacher $(30)$ & $2(6.7 \%)$ & $27(90 \%)$ & $1(3.3 \%)$ \\
\hline
\end{tabular}

Source : Field data, April, 2019

From the findings presented in Table 1 above, among 30 teachers, 27 respondents (90\%) were of the view that classrooms in the sampled schools were not adequate in relation to the number of pupils available, while $2(6.7 \%)$ responded that classrooms were enough in relation to the pupils available and 1 teacher $(3.3 \%)$ had the view that classrooms are partly or to some extent sufficient to the number of the pupils available. The findings give the impression that most of the teachers perceived that primary schools do not have adequate classrooms to suffice the number of pupils in their respective schools. As such this situation creates a difficult learning environment to the pupils and poor teaching conditions for the teachers due to classroom congestion. The findings are summarised in Table 3. 
Table 3

Pupils' Responses on adequacy of the classrooms in Dodoma Municipality

\begin{tabular}{|c|l|c|c|}
\hline $\begin{array}{c}\text { Category of } \\
\text { respondents }\end{array}$ & \multicolumn{1}{|c|}{ Responses } & Frequency & Percentage \\
\hline \multirow{2}{*}{ Pupils N=100 } & Adequate classrooms & 34 & $34 \%$ \\
\cline { 2 - 4 } & Not adequate classrooms & 61 & $61 \%$ \\
\cline { 2 - 4 } & Do not know & 5 & $5 \%$ \\
\cline { 2 - 4 } & Total number of respondents & 100 & $100 \%$ \\
\hline
\end{tabular}

Source: Field data, April, 2019

Table 3 indicates that $34 \%$ pupils said that classrooms were adequate in the schools to suffice the needs of the pupils. While $61(61 \%)$ pupils said that classrooms are not adequate to the needs of the schools, and 5 pupils $(5 \%)$ did not know whether classrooms were adequate or not. This implies that fiscal decentralization reform has not adequately helped to solve the problems of the deficit of classrooms in some of the schools. These responses confirm the findings and responses obtained from the teachers (respondents) who had similar view that classrooms were not adequate. Matete (2016) notes that there is general consensus in the literature that small classes are likely to provide effective teaching. The study by Blatchford $e t$ al.(2003) on the class size differences related to pupils' educational progress and classroom processes at the age of 5-7 years indicates that in small classes, pupils are more likely to interact with their teachers on a one-to-one basis. A pupil is also more likely to be the main focus of the teacher's attention and pupils experience more teaching, unlike in the large classes where there is a more like procedural talks.

\section{Local Government staff's response on adequacy of the classrooms in Dodoma Municipality}

Among 8 respondents from the local government staff, 6 respondents $(75 \%)$ had the view that classrooms were not adequate in primary schools due to the scarcity of funds to cater for the problems while 2 respondents $(25 \%)$ had the view that classrooms were adequate in primary schools. In other words, most of the local government staff perceived shortage of classrooms and this fact underscored the view that fiscal decentralization has not significantly enabled primary schools to have sufficient number of classrooms. The findings are summarised in table 4.

Table 4

Required, available and the deficits of classrooms in Dodoma Municipality

\begin{tabular}{|l|c|c|c|}
\hline \multicolumn{1}{|c|}{ Name schools of sampled } & $\begin{array}{c}\text { Required } \\
\text { classrooms }\end{array}$ & $\begin{array}{c}\text { Available } \\
\text { classrooms }\end{array}$ & $\begin{array}{c}\text { Deficits of } \\
\text { classrooms }\end{array}$ \\
\hline Msalato Primary School & 24 & $11(45.8 \%)$ & $13(54.2 \%)$ \\
\hline Tumaini Primary School & 10 & $5(50 \%)$ & $5(50 \%)$ \\
\hline Kizota Primary School & 30 & $11(61.1 \%)$ & $7(38.9 \%)$ \\
\hline Chidachi Primary School & 16 & $8(50 \%)$ & $8(50 \%)$ \\
\hline Kaloleni Primary School & 20 & $12(60 \%)$ & $8(40 \%)$ \\
\hline
\end{tabular}

Source: Field data, April, 2019.

Table 4 above indicates that most of the schools have severe shortage of classrooms which is almost $50 \%$ in each school except two schools such as Kaloleni and Tumain primary schools. These findings suggest that despite the fiscal decentralization reform, specifically capitation grant, development grant and capacity building grants to primary schools, school 
infrastructure such as classrooms are not adequate to suffice the needs of the pupils in most of the schools. The above findings corroborate to the findings from the performance Reports of 2004-2018 from Dodoma Municipal Council which indicate that $48.5 \%$ deficit of the classrooms in all primary schools in Dodoma Municipality.

\section{Availability and deficits of books in primary schools}

Among teachers sampled from various schools, $100 \%$ of the respondents had the view that books were not enough as such teachers are not able to give home work and assignments to the pupils during the weekends. The book to pupil ratio was said to be 1 book to 12 pupils during he teaching time. Therefore, these findings suggest that pupils cannot individually do their assignments at home. Among 100 pupils who were interviewed, 87 ( 87\%) responded that books were not enough in primary schools due to lack of adequate funds required to purchase books, while 7 pupils $(7 \%)$ were of the view that books were enough and $6(6 \%)$ pupils did not know whether books were enough or not. Therefore, most of the pupils perceived that books were not enough to suffice the needs of the pupils. Most of the pupils had the view that one book of each subject is used by twelve pupils. So most of the pupils were unable to use books individually when they are at home. According to the Council's Performance Report (June, 2018), the national book to pupils ratio is 1:1. However, in practice, this is not true because in most schools the ratio is one book to twelve pupils which indicated the shortage of books. Furthermore, this shortage according to the Council Performance Report (ibid) has been attributed to inadequate budget allocated for the learning and teaching materials.

Also similar responses arose from the local government staff on the availability and deficit of the books. Among 8 respondents, $75 \%$ were of the view that books are not enough, whilst 2 respondents $(25 \%)$ had the view that books were enough in primary schools. Similarly, documentary data corroborate the responses from respondents. In July, - Sept 2004 the expected text books to be purchased were 14,392. However, the actual number of the purchased books was 24,677 where as in Oct-Dec 2005 only 15,950 books were purchased, no books were purchased in 2006 to 2009.Thus, purchased books exceeded the targeted number of books. Despite this increase of books, most of the schools still lack enough text books because the book/pupil ratio is poor at 1:12. This presupposes that pupils cannot be able to borrow and use the books when they are at home (Dodoma Municipal Council Report, July, 2004 - June,2018). The findings give impression that most of respondents perceived that there was lack of adequate books in primary schools. The above findings suggested that fiscal decentralization had not significantly improved the availability of the books in primary schools.

\section{Availability and Deficits of Teaching Staff}

Table 5

Teachers' Responses on the Adequacy of Teaching staff in Dodoma Municipality

\begin{tabular}{|c|l|c|c|}
\hline S/N & \multicolumn{1}{|c|}{ Response } & Respondents & Percentage \\
\hline 1. & Adequate & 11 & $36.7 \%$ \\
\hline 2. & Not adequate & 18 & $60 \%$ \\
\hline 3. & Partly adequate & 1 & $3.3 \%$ \\
\hline
\end{tabular}

Source: Field data, April, 2019

Data from the table 5 shows that only 11(36.7\%) said that teachers were adequate in primary schools. While $(60 \%)$ said that teacher were not adequate in primary schools and 
only $3.3 \%$ had the view that teachers were to some extent sufficient in primary schools. This implies that fiscal decentralization has not significantly helped to increase teachers in primary schools. This has led to few teachers having many classrooms to teach and is as such unable to attend pupils in learning process. The pupils' responses to the question of availability of teachers was different $61 \%$ said that teachers are enough, while 39 pupils equal to $39 \%$ had the view that teachers are not enough. Thus, from these findings most of the pupils perceived that teachers were adequate in primary schools. These findings were contrary to the teachers' views who most of them perceived shortage of the teachers in primary schools.

Furthermore, among 8 respondents who were sampled from local government staff, $62.4 \%$ had the view that teachers are not adequate while $37.6 \%$ had the view that teachers are adequate. Therefore, most of respondents from the local government staff perceived that the teachers in primary schools were inadequate. These findings confirm to the responses from the teachers. Basing on these findings, it is clear that most of the LGA respondents and teachers had the view that fiscal decentralization had not significantly helped primary schools to have adequate teachers although pupils have perceived differently. In the same vein, the Performance Report (June, 2018) indicated that there was deficit of $11.6 \%$ of teachers as it is indicated in the table 6 below.

Table: 6

Indicates the Availability of Teachers in Primary Schools in Dodoma Municipality

\begin{tabular}{|c|c|c|c|}
\hline Teachers 'demand & Available & Deficit & \% Deficit \\
\hline 1,677 & 1,483 & 194 & 11.6 \\
\hline
\end{tabular}

Source: Dodoma municipal performance report, June, 2009 to 2018

\section{Availability and deficits of Teachers' Houses}

Teachers' responses on the availability and deficit of the teachers' house indicated that most of the schools do not have adequate teachers' houses as such most of the teachers hire houses using their low salaries. Among 30 teachers who responded; all of them said that schools did not have enough houses for the teachers as such only few teachers are given houses in primary schools.

Table 7

Allocation of Houses to Teachers in Dodoma Municipal Council

\begin{tabular}{|c|l|c|c|c|}
\hline S/N & \multicolumn{1}{|c|}{ Names of schools } & $\begin{array}{c}\text { Total number of } \\
\text { teachers } \\
\text { available }\end{array}$ & $\begin{array}{c}\text { Houses available in } \\
\text { Schools }\end{array}$ & $\begin{array}{c}\text { Percentage of } \\
\text { teachers } \\
\text { given houses }\end{array}$ \\
\hline 1. & $\begin{array}{l}\text { Kaloleni Primary } \\
\text { School }\end{array}$ & 34 & 1 & $(2.9 \%)$ \\
\hline 2. & $\begin{array}{l}\text { Msalato } \\
\text { Primary School }\end{array}$ & 18 & 6 & $(33.3 \%)$ \\
\hline 3. & $\begin{array}{l}\text { Chidachi } \\
\text { Primary School }\end{array}$ & 20 & 0 & - \\
\hline 4. & $\begin{array}{l}\text { Tumaini } \\
\text { Primary School }\end{array}$ & 20 & 0 & $(5.4 \%)$ \\
\hline 5. & Kizota Primary School & 37 & 2 & \\
\hline
\end{tabular}

Source: Field data April, 2019

From the Table 7.0 above, only $9(7 \%)$ of teachers were given houses among 129 teachers in the sampled schools. However, 120 (93\%) of the teachers were not given houses in their primary schools. Therefore, the capitation and development grants given to schools by the 
government as part of fiscal decentralization toward improving primary education services has not adequately helped to ensure adequate houses for the teachers in primary schools. Also, LGA respondents had similar views. Among 8 respondents, $75 \%$ said that teachers' houses were not adequate to suffice the number of teachers available, while $25 \%$ had the view that teachers' houses were enough. Thus, the findings corroborate the responses of the teachers who had the view that houses are not adequate in primary schools.

Furthermore, among 100 pupils, 95\% respondents said that teachers' houses were not enough, and $5 \%$ of pupils said that they do not know whether teachers houses were adequate or not. So the above findings confirmed similar responses to the findings from the teachers' responses and local government staff. Similarly, the Dodoma Municipal's Performance Report, (June, 2018) indicates a shortage of the teachers' houses of almost $89 \%$ percent of the deficit as shown in the table 8 below:

Table 8

The availability of Teachers' Houses in Dodoma Municipal Council

\begin{tabular}{|c|c|c|c|c|}
\hline $\begin{array}{c}\text { Type of school } \\
\text { infrastructure }\end{array}$ & Required & Available & Deficit & \% of deficit \\
\hline Teachers Houses & 1483 & 169 & 1314 & $88.6 \%$ \\
\hline
\end{tabular}

Source: Field data, April 2019

Therefore, from the Table 8 above only 169 teachers (11.4) among 1483 teachers were given school houses in Dodoma municipality while 1314(88.6\%) of the teachers were not given school houses because of lack of the adequate funds and conditional grants provided to Dodoma municipal council. So from the above documentary data and responses from respondents, it was clear that teachers' houses were adequate given the number of teachers i.e 1483 available.

\section{Availability of Desks in Primary Schools}

Most of the respondents from the teachers had the view that desks were not enough in their schools. 25 teachers $(83.3 \%)$ had the view that desks were not enough in primary schools, whilst $16.7 \%$ of teachers said that desks were sufficient for the pupils. Similarly, among 100 pupils, $70 \%$ of them had the view that desks were not adequate to suffice the needs of the pupils in primary schools. And 30\% of the pupils perceived adequacy of desks. Therefore most of the pupils perceived shortage of desks in primary schools. One respondent from this group had this to say; "Desks are not enough in many primary schools especially in our school that is why standard one and some of standard two are studying while sitting the floor in their class rooms." In the same vein, the above responses confirmed to the findings obtained from the Council's Report (June, 2018) which indicated the deficit of $46 \%$ of the desks in primary schools. So, these findings evidenced that fiscal decentralization reform local particularly to Dodoma municipal council had not adequate funds and financial management autonomy for purchasing primary school infrastructure such as desks.

Also responses from the local government staff ( 8 ) corroborate to the pupils and teachers views, 6 of them (80\%) said that desks were not enough in the primary schools due to lack of adequate funds for school infrastructures. But $20 \%$ respondents said that desks were enough in primary schools. So from these findings most of the respondents perceived the inadequacy of the desks in primary schools in Dodoma municipal council. Furthermore, the Council's Performance Report (2007-2019) indicated that expected desks to be provided to the schools using development grants in April 2007 to June, 2009 were 2,960 desks. However because of inadequate funds provided by central government only 417 desks $(14 \%)$ were made and given 
to schools. So $86 \%$ of the desks were not availed to schools because of lack of adequate funds needed by Dodoma municipal council to cater for the desks.

Therefore, to sum up, still local authorities in Dodoma municipality did not have the adequate finances and financial control autonomy for the school infrastructures such as desks as perceived by respondents, from pupils, teachers as well as local government staff and documentary findings.

From the Table 9. above, the findings indicated that among 30 teachers , 25 (83.3\%) had the view that enrolment has increased due to abolition of school fees and the increase of the parents' awareness while $16.7 \%$ of respondents said that enrolment has not increased. Therefore, in this category of the respondents, most of the informants perceived increase of enrolment in schools.

\section{The Trend of enrolment of Pupils in Primary Schools}

Table 9

\section{Responses on whether enrolment has increased in primary schools}

\begin{tabular}{|c|l|c|c|c|c|}
\hline S/N & Type of respondents & \multicolumn{2}{|c|}{ Category of responses } & Total no. of Respondents \\
\hline & & Yes & No & $\begin{array}{c}\text { Do not } \\
\text { know }\end{array}$ & \\
\hline 1. & Teachers & $25(.83 .3 \%)$ & $5(16.7 \%)$ & 0 & $30(100 \%)$ \\
\hline 2. & Pupils & $70(70 \%)$ & $30(30 \%)$ & 0 & $100(100 \%)$ \\
\hline 3. & $\begin{array}{l}\text { Local government } \\
\text { staff }\end{array}$ & $5(62.5 \%)$ & $3(37.5 \%)$ & 0 & $8(100 \%)$ \\
\hline
\end{tabular}

Source: Field data, April, 2019.

Also, pupils had similar responses $70 \%$ said that enrolment has increased due to the abolition of the school fees and increase of awareness to the general public on the importance of education, but 30 respondents $(30 \%)$ perceived that enrolment since financial decentralization reform started had not improved. Thus, most of the pupils said there was the increase of enrolment in primary schools.

Furthermore, among 8 respondents from the local government staffs.5 (62.5\%) had the view that enrolment of standard one in primary schools had increased significantly, while $37.5 \%$ said that enrolment had not increased in primary schools. The findings give impression that most respondents from the pupils, teachers and Local government staff had the view that enrolment of standard one in primary schools had significantly improved due to the abolition of school fees and increase of the awareness of the parents particularly on the importance of education. The above responses corroborate to the findings obtained from the Local government performance report (June,2018) as indicated from 2006 to 2018 enrolment remained at the average of 95.5 in primary schools.(See Table 10).

Table 10

Enrolments in Grade I - VII Since 2015 to 2018 in Dodoma

\begin{tabular}{|c|c|c|c|c|}
\hline Year & \multicolumn{4}{|c|}{ Total Enrolled std I - VII } \\
\hline & Boys & Girls & Total & \% of enrolment \\
\hline 2015 & 30217 & 31607 & 61824 & $97 \%$ \\
\hline 2016 & 31694 & 31883 & 63577 & $98 \%$ \\
\hline 2017 & 3853 & 31763 & 63616 & $94.5 \%$ \\
\hline 2018 & 33459 & 33605 & 67064 & 93 \\
\hline
\end{tabular}

Source: Field data 2015 to 2018 
From the above Table 10, it indicates that in 2015 there was $97 \%$ of the pupils who were enrolled, thus only $3 \%$ of the boys and girls were not enrolled in standard one in primary school. Thus, it suggested that there was increase of enrolment of the pupils in primary schools. .Further more, in 2016, $98 \%$ of the pupils (boys and girls) were enrolled in primary schools so only $2 \%$ of the expected boys and girls were not enrolled due to the inadequate awareness and ignorance to their Parents. Also in 2017 enrolment was $94.5 \%$ and decreased at the rate of $3.5 \%$ compared to previous year which was $98 \%$ in 2016 although it remained at the average of $95.5 \%$ which shows that still there was significant improvement. Additionally, in 2019 enrolment further decreased at rate of 1\% compared to last year (2008) which was 93\% were enrolled in standard one. Thus, the above findings presuppose that the enrolment of standard one in primary schools has further remained at the average of $95.5 \%$. This was attributed to abolition of school fees and increase of awareness of the parents particularly on importance of education.

\section{Responses on the Pattern or trend on Academic performance}

Table 11

Shows responses of Teachers on academic performance in primary schools

\begin{tabular}{|c|c|c|c|}
\hline Category of respondents & Responses & Respondents & Percent of responses \\
\hline Teachers N=30 & Yes & 19 & $62.5 \%$ \\
\hline & No & 11 & $37.5 \%$ \\
\hline & Don't know & - & - \\
\hline
\end{tabular}

Source : Field data, April 219

From the Table 11, among 30 teachers, 19 respondents $(63.5 \%)$ had the view that the pattern of academic performance was poor as it was decreasing. while $11(36.5 \%)$ respondents said that the academic performance to the standard seven is increasing. From these responses, it indicated that most of the respondents had the view that the trend of academic performance to the standard seven was poor as it was decreasing. Additionally, local government staff responded through interviews $5(62.5 \%)$ of them had the view that the pattern of academic performance in standard seven examination is decreasing, and $3(37.5 \%)$ said that the trend of academic performance is increasing in standard seven examination.

Therefore, most of respondents from the Dodoma municipal council had the view that fiscal decentralization has not significantly improved academic performance in the council .This aspect was attributed to shortage of school infrastructures such as desks and classrooms which led to poor learning environment for the pupils. Other factor was lack of learning materials such as books and teaching aids to the teachers and pupils. The above findings were similar to pupils' responses in schools that the trend of academic performance in standard seven examinations was poor and was decreasing. $64 \%$ of pupil had the view that the pattern of academic performance was decreasing, while, 36 (36\%) said that the trend of academic performance was increasing. so most of the respondents from the pupils perceived low performance in standard seven exams despite the fiscal decentralization reform. These responses also corroborate to the findings obtained from the council performance report (June, 2009) as Table12 below indicates:

Table 12

The Pattern of Academic Performance in Primary Schools from 2001 to 2018

\begin{tabular}{|c|c|c|c|c|c|c|}
\hline Year & \multicolumn{3}{|c|}{ No of Candidates } & \multicolumn{3}{c|}{ Candidate passed } \\
\hline & Boys & Girls & Total & Boys & Girls & Total \\
\hline 2001 & 2049 & 2326 & 4375 & 967 & 905 & 47 \\
\hline
\end{tabular}




\begin{tabular}{|c|c|c|c|c|c|c|}
\hline Year & \multicolumn{3}{|c|}{ No of Candidates } & \multicolumn{3}{c|}{ Candidate passed } \\
\hline & Boys & Girls & Total & Boys & Girls & Total \\
\hline 2002 & 2709 & 2892 & 5601 & 662 & 277 & 16.05 \\
\hline 2003 & 2461 & 2620 & 5081 & 1225 & 986 & 43.5 \\
\hline 2004 & 2198 & 2485 & 4683 & 1418 & 1288 & 57.83 \\
\hline 2005 & 1747 & 1693 & 3440 & 1559 & 1462 & 87.82 \\
\hline 2006 & 2670 & 2816 & 5486 & 2464 & 4956 & 89.6 \\
\hline 2007 & 3403 & 3232 & 6637 & 2399 & 1750 & 63 \\
\hline 2008 & 3993 & 3813 & 1806 & 2813 & 2206 & 64 \\
\hline 2009 & 3751 & 4010 & 7761 & 2292 & 2060 & 56 \\
\hline 2018 & 4511 & 5223 & 9734 & 3241 & 4112 & 75.5 \\
\hline
\end{tabular}

Source: Dodoma Municipal Performance Council's Report, June, 2018

The Table 12, above indicates that the pattern for academic performance was decreasing since it varied from one year to another. Similarly, academic performance was decreasing as shown in the percentage of the candidates passed standard seven exams from 2001 to 2009. The highest percentage of academic performance was $89.6 \%$ in 2006 which decreased to 56\% in 2009 and increased to $75.5 \%$ in 2018 . This situation is attributed to increase of enrolment of pupils in standard one while there were no enough funds, teachers, and classrooms to meet the number of pupils. The findings corroborate with the Citizen News Paper, $8^{\text {th }}$ January, Sunday 2017 which notes that pass rate at primary school level have fluctuated wildly between 2003 and 2013 plummeting from high 70.5 percent in 2006 to down 30.7 percent in 2012.

\section{Discussion of The findings}

The study investigated the fiscal decentralization reform and its effect on primary education service delivery and analyzed whether the devolution of functions specifically primary education service delivery have enabled the council to achieve qualitative and quantitative distribution of primary education services. The study findings indicate that Dodoma municipal council does not have autonomy of deciding on the amount of funds to be disbursed to it for primary education services, as indicated by respondents from the teachers, pupils and the local government staff. Further more, the study indicated the extent to which the council has failed to fulfil its roles and improve primary education service delivery in terms of school infrastructures, furniture and in long run academic performance. For instance, primary schools are poorly equipped, classes are inadequate with pupil classroom ratio at 1:72 (ideally 1:40) and pupil latrines ratio hovering around 1:52 (ideally 1:22.5) and only $20 \%$ of primary schools have access to electricity (The Citizen News Paper, $8^{\text {th }}$ January, Sunday 2017).

Also, the study indicated that there is tremendous increase of enrolment in standard one due to the abolition of school fees and increase of parents' awareness on the necessity of education although schools experienced shortage of teachers, learning and teaching resources.

The study was guided the theory of fiscal decentralization by devolution to assess whether the latter reflects the devolution of functions particularly primary education function and the financial capacity and autonomy of the council. However the findings indicated that the council did not have the financial capacity to deliver qualitative and quantitative primary education service delivery.

Also, the theoretical framework was used in assessing whether the devolved functions in this case primary education function can be fulfilled adequately using finances devolved to the council through own sources of revenues and grants disbursed by central government to 
the council. However, the study revealed that the council's devolved functions were not similar with the financial capacity and control autonomy of the council. Therefore, the council still operated under financial constraints and lack of autonomy which affected negatively primary education service delivery in the council. The study found that a service delivery specifically primary education service has not been adequately improved despite fiscal decentralization reform in Tanzania. Justification for lack of improved primary education services are indicated by lack of adequate text books to both teachers and pupils, inadequate classrooms, lack of enough desks, teacher's houses, inadequate salaries, delay the salaries and allowances to the new teachers in primary schools. Therefore, the findings in the study supported the view that lack of the financial control and management autonomy contribute to poor primary education service delivery in Tanzania.

\section{Conclusion}

From the study's findings, it was noted that there was a problem of lack of autonomy in financial control and management to the councils which contributed to poor performance of the local authorities in primary education service delivery despite the implementation of fiscal decentralization reform in Tanzania. There had been frequent central government interference in financial control, utilization and management of the council as supported by many respondents and Councils' Performance Reports (2000-2019). Things that undermine the councils' autonomy were noted in grants attached with the conditionality, decisions on the amount of money from the central government which constrain the priorities and needs of local government and respective schools. This denies councils autonomy in financial management and utilization matters to the extent that local government fails to provide qualitative and quantitative primary education service delivery in Tanzania. A part from lack of financial management, the study identified other factors that contribute to poor performance of the local government authorities. These included lack of adequate funds in local government authorities and lack of commitment of the teachers. However, it is important to note that the persistence of these problems was a result of lack of financial management autonomy in the council and its poor capacity to fulfil the devolved functions, effectively and efficiently. The study therefore, is of the view that the practice of fiscal decentralization to local councils in Tanzania does not complement the devolution of the functions to local council particularly the delivery of primary education services resulting in poor services. The Local Government Policy (1998) is very clear and explicit as it advocates objective criteria on disbursement of funds and fairness to the council but the practice deviates from the reality as it is indicated by the findings.

This appears to be main reason why primary education service to the public in the council has not substantially improved. Therefore, while on the one hand, the government is committed to implement fiscal decentralization reform in the form of devolution of finances and devolution of functions. In the other hand, it has not devolved adequate power to manage funds as they are do not suffice the needs of primary school services. Thus, fiscal decentralization reform continues to be better in theory but not effective in practice. If the Central government is really committed to reform local government in the aspect of fiscal decentralization in order to improve primary education service delivery in local authorities in Tanzania should ensure financial autonomy in the council and the funds are to be disbursed on time in primary schools so that primary education services are provided as expected.

\section{Recommendations for further research}

More studies are needed in examining and assessing various components of the reform in local government authorities in Tanzania. This study was mainly concerned with only one of 
the components of the reform that is fiscal decentralization reform and its effects in performance of local government authorities particularly in primary education service delivery. Therefore, there is a need to conduct many studies as possible to assess other aspects of reform, such as political, administrative, functions decentralization reform and other aspects which have not been considered in this study. One among many areas researcher may conduct study on the same research on other local governments in Tanzania so that to have comparative analysis whether fiscal decentralization reforms have improved service delivery in other municipalities, district and city councils.

\section{Study Limitations}

This study acknowledges that the findings are specific to Dodoma Municipal Council and therefore the generalization to other LGAs is limited. The restricted sample size of 138 (Teachers, Pupils and local government staff) posed a noticeable limitation, ruling out the question of generalizability. Firstly, the study may be replicated and should include respondents that were not represented in this study like President's Office-Regional Administration and Local Governments to provide further evidence of the generalizability and robustness of the study. The study was also limited by its method used in choosing respondents, that is, a non-probability purposive sampling method. It is therefore recommended that future research in this context uses a probability sampling technique so that subjects of the population get an equal chance of being selected as a representative sample.

\section{Acknowledgement}

This work is a result of contributions from a number of individuals and institutions. Though I cannot mention them all, some require a special mention. First and foremost, I thank God for the blessings that facilitated the completion of this work. Secondly, I would like to sincerely thank Prof. Dmitri Bondarenko and Prof. Fituni, L. for their tireless guidance on the international journal where this manuscript is published. Similarly, I express my sincere thanks to the Dodoma Municipal Council's staff in Tanzania for their willingness to give relevant data and information for this study.

\section{References}

Blatchford, P; P. Bassett; H. Goldstein and C. Martin. (2003). Are Class Size Differences Related to Pupils' Educational Progress and Classroom Processes? Findings from the Institute of Education Class Size Study of Children Aged (5-7) Years. Institute of Education, University of London.

Crook C.R and Manor ,J, (1998). Democracy and Decentralization in South Asia and West Africa, Cambridge University press.

De Mello. D.L. (1982). Local Government and National Development Strategies, a Latin American Perspective: Planning and Development Vol.9.No.2.

Dodoma Municipal Capacity Building plane for the financial years 2017/2018.

Dodoma Municipality (2005-2018). Primary Education Development Programme: Performance Report, April - June 2018. Dodoma.

Economic Research Bureau (1997). Towards A Matching Principle for Dutch Supported Districts in Tanzania. Dar es Salaam.

Enumuo F.C (2000). Problems and Prospects of Local Governance: chapter 7 [pp. 181-204] in G.Hayden, D, Oluwu and H. Ogendo (eds) African Perspective Of Governance. Trenton / Asmara: African World press.

Fjelstad, H, O (2003). Fiscal Decentralization in Tanzania: for Better or for Worse? Journal of public Administration Vol. 38, No. 2 (June) PP. 133-147. 
Fjelstad, O. H. and Semboja. O. (2001). Why People Pay Taxes, The case of Development Levy in Tanzania, Word Development Vol. 29 No. 12, PP. 2059 - 2074 (December).

Fjelstad, O.H. (2003). Formative Process Research On Local Government Reform In Tanzania [FPR]: Citizen Survey Report. Bergen Chr. Michelsen Institute (November, 2003).

Galabawa, J. (1990). Implementing Educational Policies in Tanzania. World Bank Discussion Papers Africa Technical Department Series, WDP-86.

Haule, M. and Ngware, S. (1992). The Forgotten Level Village Government in Tanzania. Institute for Africa. Kunde.

Kessy, T.A. (2011). Local Governance Reforms in Tanzania: Bridging the Gap between Theory and Practice in "Democratic Transition in East Africa: Governance and Development at the Grassroots". Research and Education for Democracy in Tanzania (REDET).

Liviga, A.J. (1992).' Local Government in Tanzania - Partners in Development or Administrative Agent of Central Government. Local Government Studies: Vol. 18, Issue No. 3.

Livingston, I, and Charton, R, (1998). Raising Local Authority District Revenues Through Direct Taxation In The Low Income Developing Country Evaluating Uganda GPT. Public Administration and Development, Vol. 18, PP. 499-517.

Local Government Policy Paper on Local Government reform, (1998) Dar- es-Salaam; Tanzania.

Matete, R. (2016). Challenges Facing Primary Education under Decentralization on Primary School Management in Tanzania. International Journal of Humanities and Social Science. Vol. 6, No. 1; January 2016.

Max, J, (1991). The Development of Local Government in Tanzania. Education publisher and distributors Ltd, Dar es-Salaam.

Mtasigazya, P. (2018a). Cost-Effectiveness of Outsourcing Local Government Revenue Collection in Tanzania: The Case of Kinondoni and Morogoro Municipal Councils. PEOPLE: International Journal of Social Sciences, 4(2), 1554-1571.

Mtasigazya, P. (2018b). Contract Management in Outsourced Revenue Collection in Local Governments in Tanzania: Experience from Selected Local Government Councils: Journal of the Institute For African Studies, Vol.4 (45), 32-50.

Mtasigazya, P. (2018c). The Impact of Outsourcing on Local Governments' Revenue Collection Performance in Tanzania: Experience from selected Councils. International Journal of Technology and Management Vol. 3. Issue II p. 18, Dec. 2018.

Mtasigazya, P. (2019). The Efficacy of Tendering Process on Outsourced Revenue Collection in Local Governments in Tanzania: Experience from Selected Local Governments Councils: PEOPLE: International Journal of Social Sciences, 4(3), 1712-1729.

Mukandala, S.R. (2000). African Public Administration .A Reader, Harare, Zimbabwe,

Mwaikyusa, J.T. (1998). Control of Local Government Authorities in Tanzania. RAP: Institute of Development Management.

Ndalichako, J. and Roy C. H. (2005).Education Situation Analysis, Final Report $29^{\text {th }}$ December, 2005 Dar - es - Salaam, Tanzania. International Consultants provided by ARCADIS/SPAN, Netherlands, National Consultants provided by Economic and Social Research Foundation, Dar es Salaam, Tanzania.

Ngware, S. and Haule M. (1992). The Forgotten Level. Village Government in Tanzania. Humburg: Institute for Africa-Kunde.

Nyalali, F. (1992). The Nyalali Commission Report. Dar es Salaam

Oates W.E (1993). Fiscal Decentralization and Economic Development, National Tax Journal Vol.46 No.2. P.237-243.

Regional Education Development Programme (2009-2018). Performance Report April - June, Dodoma, 2018.

Smoke, P,(2001). Fiscal Decentralization in Developing Countries: A Review of Current Concepts and Practice: Democracy, Governance and Human Rights Programme. Democracy, Governance and Human Rights Programme Paper Number 2 February 2001, February. United Nations Research Institute For Social Development.

United Republic of Tanzania (URT) (2001). The Education And Training Sector Development Program Document, Dar es Salaam. Ministry of Education and Culture, Tanzania.

United Republic of Tanzania (2005). Decentralization for Service Delivery in Tanzania. A paper presented by D.M.S. Mmari, Permanent Secretary, President's Office, Regional Administration and 
Local Government, United Republic of Tanzania, at the conference on Building Capacity for the Education Sector in Africa. Oslo, Norway October 12th - 14th 2005.

URT (2002). Law of Tanzania Principal Legislation, Vol. VII, Junta and Company Limited, Cape Town.

URT. (1977). The Constitution of the United Republic of Tanzania.

URT (2012). Population Census in Tanzania. Dar es Salaam.

The Citizen News Paper, $8^{\text {th }}$ January, Sunday 2017.

Warioba M.D. (1999). Management of Local Government in Tanzania: Some Historical Insights and Trends. Research Information and Publication, Mzumbe, Tanzania.

World Bank (1999). World Development Report 1999/2000: Entering the 21st Century: The Changing Development Landscape, London/ Newyork 


\section{РЕФОРМА ФИСКАЛЬНОЙ ДЕЦЕНТРАЛИЗАЦИИ И ЕЕ ВЛИЯНИЕ НА СИСТЕМУ НАЧАЛЬНОГО ОБРАЗОВАНИЯ В ТАНЗАНИИ: НА ПРИМЕРЕ МУНИЦИПАЛЬНОГО СОВЕТА ДОДОМА}

\section{(C) 2019 Пол Мтэзигэзья (Танзания)}

МТЭЗИГЭЗЬЯ Пол, доктор наук, Кафедра социальных исследований, Академия Мвалиму Ньерере. Занзибарский кампус, п/я 307, Занзибар. Танзания, e-mail: p.anton75 @yahoo.com, мобильный телефон: +255714449030

Аннотация. Исследование о реформах фискальной децентрализации, проводимых в органах местного самоуправления (LGAs) в Танзании, с особым акиентом на изучении состояния начального образования в муничипальном совете Додомы основано на данных, собранных посредством интервью и обзоре документов. Несмотря на реформы, направленные на передачу финансовых полномочий совету, работа мунищипального совета, в частности, в области предоставления услуг начального образования, оченивается как посредственная. Отмечается, что несмотря на реформы фискальной децентрализации все еще не наблюдается значительного улучшения в предоставлении услуг начального образования. Практика фискальной децентрализачии, такая как межбюджетные трансферты, гранты и собственные источники доходов местных органов власти, не приводит к желаемому результату. Совет не располагает достаточным количеством финансовых средств. Реформа не предусматривает расходы на школьную инфраструктуру, мебель и на улучшение успеваемости по семи стандартным экзаменам. Недостаток средств, выделяемых совету, привел к низкому уровню начального образования. Автор приходит к выводу, что для того, чтобы уровень начального образования вырос, совет должен получить финансовую независимость.

Ключевые слова: реформа фискальной децентрализации, предоставление начального образования

DOI: $10.31132 / 2412-5717-2019-48-3-30-48$ 